\title{
Market Structure, Price Formation and Price Transmission for Wood Charcoal in Southeastern Nigeria
}

\author{
Agbugba, Ikechi Kelechi ${ }^{1} \&$ Ajuruchukwu Obi ${ }^{1}$ \\ ${ }^{1}$ Department of Agricultural Economics \& Extension, University of Fort Hare, Private Bag X1314, Alice, South \\ Africa \\ Correspondence: Ajuruchukwu Obi, Department of Agricultural Economics \& Extension, University of Fort Hare, \\ Private Bag X1314, Alice, South Africa. Tel: 27(0)-73-313-1865. E-mail: aobi@ufh.ac.za
}

Received: March 8, 2013 Accepted: May 5, 2013 Online Published: September 15, 2013

doi:10.5539/jas.v5n10p77 URL: http://dx.doi.org/10.5539/jas.v5n10p77

\begin{abstract}
Due to the Federal Government of Nigeria's privatization and commercialization of the downstream sector of the oil industry, the prices of kerosene and gas, which are competitors to wood charcoal, have risen astronomically in recent years. This has also continued to shift demand away from them and back to wood charcoal. Wood charcoal business is, therefore, fast becoming a lucrative business in Nigeria. However, for agro-climatic reasons, production of wood charcoal is mostly concentrated around the forest regions of the country thereby underscoring its marketing as a very important component of the business environment with potential for mass employment creation and poverty alleviation. But no systematic assessment of this potential has been carried out to date. This paper examines the marketing of wood charcoal in Abia State Nigeria, especially as it concerns the margins, structure, price causality, and price transmission. The margins were however on the average, lower than the producer's share of the consumer spending. The result of the analysis also suggests a competitive market structure for wood charcoal in the study area. Prices were determined at the producer level of the marketing chain, but producers were asymmetric in their price transmissions to the wholesale level. These observations suggest that policy intervention in the form of improving the socio-economic environment under which marketing agents operate and facilitation of market information flow (which could reduce the asymmetric behavior of producers) could improve marketing of wood charcoal in the study area, with important practical implications for poverty alleviation and food security.
\end{abstract}

Keywords: wood charcoal, marketing margins, price transmission, market structure, asymmetric information, Nigeria

\section{Introduction}

Wood charcoal is one of the major components or fractions of wood fuel. Wood charcoal is processed from wood and wood materials from trunk, branches and other parts of trees and shrubs, processed by burning and passing through fire. According to the Food and Agriculture Organization of the United Nations (FAO), charcoal is the solid residue derived from controlled combustion of a wide range of materials under conditions of limited supply of oxygen (FAO, 1983). The United States Department of Agriculture (Forest Service) documented the production of wood charcoal in a 1961 report (USDA, 1961) which indicates that high-temperature heating of wood products results in the production of a wide range of by-products that include a solid object known as "Charcoal". The resulting object is a black, charred material that has a distinct texture and appearance and used mainly for cooking, heating or generating energy through direct combustion (Food and Agricultural Organization, 1981). It has been a part of African culture for hundreds of years because it has been a part of everyday life, and is essentially used for cooking, and also for food production (Agbugba, 2008).

According to Walton (1974), wood produced from forest trees are used in the following ways: $40 \%$ used for the production of wood fuel which comprises mainly charcoal and fuelwood, and approximately $60 \%$ is used in wood industries as solid lumber for building, plywood veneers; wood pulp for paper making; extracts such as turpentine, resins, waxes, soils, dyes, rubber and tanbark.

Wood charcoal yields a larger amount of heat in production than is obtained from a corresponding quantity of wood and has the further advantage of being smokeless. Wood charcoal is used mainly as fuel. It is often used in blacksmithing, a vital component of rural industrialization that plays an important role in the fabrication of low 
cost farm and domestic appliances. One of the most important applications of wood charcoal is as a component of gunpowder. It is also used as a reducing agent in metallurgical operations, but this application was diminished by the introduction of coke, which is a high quality carbon derivative produced by the destructive distillation of bituminous coal and is a vital input in the production of industrial steel. Due to the structure and porous nature of wood charcoal, it is a highly efficient agent for filtering the absorption of gases as well as solids from solutions, but this is accomplished more efficiently by animal charcoal (Cognitive Enhancement Research Institute, 2013).

According to Centre for International Forestry Research (2005), wood fuel is Africa's primary energy source for at least $70 \%$ of households. It is the major source of energy in rural areas both for domestic uses, in small-scale traditional industries and commercial enterprises. Though inefficient, wood charcoal production and distribution contribute to some extent, the national balance of payments at the macro level as foreign exchange. In Nigeria, the wood charcoal enterprise is one of the major components of the wood fuel industry and it is the main source of domestic fuel in urban areas, accounting for more than half of the domestic energy consumption (Enete \& Agbugba, 2008).

Current trend for wood charcoal shows a rising demand (CIFOR, 2005). Urban demand has created markets of wood charcoal for both men and women. Men are involved in long distance trade in wood charcoal and firewood, whereas women are involved in small-scale wood charcoal trade. Poor urban women are said to pay higher prices for charcoal owing to its inefficient marketing. In rural areas, women and children walk long distances to produce, harvest and transport wood charcoal to their households.

Wood charcoal is one of the notable woodfuel which is more reliable than any of its competitors such as gas, electricity or kerosene. It is therefore more likely to be in demand for domestic purposes for very many years to come. For instance, a survey of both urban and rural communities in Southwestern Nigeria showed that about 95\% of households depend on wood charcoal and other wood fuels for cooking (Ogunkunle \& Oladele, 2004). As a result, wood charcoal is no longer a freely available product especially in urban areas in Nigeria.

The wood charcoal market is a point of sale for wood charcoal approved by their management structure. Such a market is supplied by a usage cutting area, the boundaries of which are defined by common agreement between the management and the forestry administration until such a time as decentralization is implemented (Morgan \& Moss, 1981). The objective of the market is to alter not only the flows of wood from the spatial and quantitative standpoints, but also to change the terms of trade by increasing the share of the local population in the earnings from the activity.

Marketing of wood charcoal is gradually developing interest and therefore becomes a vital component of the industry. The marketing systems is said to perform vital functions, one of which is the allocation of resources through the price system (Enete \& Agbugba, 2008). The price of wood charcoal is said to determine the income and economic welfare of wood charcoal business households which in turn influences their investment and production decisions. However, the production of wood charcoal is most likely to be concentrated around the forest regions of the country, thereby giving rise to a lot of distributional problem. The demand and supply situation of wood charcoal in Nigeria is such that areas of shortages exist along with areas of surpluses (Ardyafio-Schandorf, 2006).

Moreso, with the current economic reforms of the Federal government of Nigeria, as well as the concomitant privatization and commercialization of most public utilities, the prices of competitors to wood charcoal have continued to sky rocket. This has naturally continued to shift consumption away from these competitors and back to wood charcoal particularly in urban areas (Ogunkunle \& Oladele, 2004; Agbugba, 2008).

Available report shows that most of the research efforts on wood charcoal have tended to concentrate on the environment and population concerns of wood charcoal usage (Garland, 2006). Consequently, Woodhead (2005) pointed out that very few studies have specifically focused on marketing of wood charcoal in Nigeria and other sub Saharan African countries. This paper examines the marketing of wood charcoal in Southeastern Nigeria, especially as it concerns structure, margins, price causality and transmission.

\section{Methodology}

The study was conducted in Abia, a Southeastern state of Nigeria. Abia state which was created in August 27th 1991 out of old Imo State comprises seventeen (17) Local Government Areas which fall into three agricultural zones namely Abia North (or Ohafia), Abia Central (or Umuahia) and Abia South (or Aba) agricultural zones (Ministry of Chieftaincy Affairs, Abia State Government, 2010). Abia State lies within latitudes $4^{\circ} 48^{\prime} \mathrm{N}$ and $6^{\circ} 10^{\prime} \mathrm{N}$ and longitudes $7^{\circ} 09^{\prime} \mathrm{E}$ and $8^{\circ} 04^{\prime} \mathrm{E}$ (Ministry of Lands, Survey and Urban Planning, Abia State Government, 2010). Abia State has a total population of 2,833,999 persons comprising 1,434,193 males and 
$1,399,806$ females, while its population density is 486 persons per square kilometer (National Population Commission, 2006). The state has a land area of $5,834 \mathrm{~km}^{2}$ or 583,377 ha. For this study, an urban-rural approach was adopted in the sampling of the respondents. This is because wood charcoal is mostly consumed in the urban areas. The study purposively selected the urban centres in each of the three agricultural zones. With the assistance of a key informant, a compilation of wood charcoal wholesalers was carried out in each of the urban centres. From the list, a random sample of 15 wood charcoal wholesalers was selected in each of the three agricultural zones. From the retailers, three retail markets were randomly selected in each of the urban centres which a list of wood charcoal retailers compiled for each market. From the list, five retailers were randomly selected making it 15 retailers from each of the urban centres in the agricultural zones. The information got from the wholesalers or distributors on their sources (village) of supply of wood charcoal, a total of 15 producers were randomly selected in each of the agricultural zones. The total number of 135 respondents comprised the sample size for the study.

\subsection{Data Collection}

A structured questionnaire was employed to collect primary information from the selected respondents. In addition to this, information was collected through oral discussions and direct measurement. Over a period of one month, prices were collected on a daily basis from sellers at the producer, wholesaler and retailer levels of the coal marketing system. This procedure was repeated in all the locations from which the study sample was drawn.

\subsection{The Models}

With regards to the market structure for wood charcoal dealers, the Gini coefficient was used to measure the degree of inequality in their volume of trade. Gini coefficient is a number or an index varying between zero and one; zero signifying perfect equality, and one perfect inequality. According to the United Nations Development Programme (1992), Gini coefficients for countries with high inequality typically lie between 0.5 and 0.7 . The formula for Gini coefficient is shown below:

$$
G=1-\sum_{k=o}^{k=n-1}\left(\partial Y_{k-1}+Y_{k}\right)\left(\partial X_{k-1}-X_{k}\right)
$$

Where

$$
\begin{aligned}
& \mathrm{G}=\text { Gini Coefficient; } \\
& \mathrm{X}=\text { Marketing Agents; } \\
& \mathrm{Y}=\text { Volume of Trade; } \\
& \partial \mathrm{X}=\text { Cumulated proportion of Wood Charcoal marketers; } \\
& \partial \mathrm{Y}=\text { Cumulated proportion of Sales (volume of trade); } \\
& \mathrm{n}=\text { Number of observations; } \\
& \mathrm{k}=\mathrm{n}-1 \text { (number of observation minus } 1 \text { ). }
\end{aligned}
$$

NOTE: The sales volume of wood charcoal is the value of wood charcoal sold by dealers in the market at each level. The marketing agents signify the number of respondents at each level.

In line with the procedure employed by Guvheya et al. (1998) for analyzing the price transmission in the market for horticulture in Zimbabwe, causality tests were implemented. The purpose of these tests are normally to make it possible to identify the direction in which price flows along the chain, for instance, among diverse agents/market participants such as producers and wholesalers and retailers of wood charcoal. By this process, it is possible to more precisely establish the point on the marketing chain at which wood charcoal price determination takes place. In this regard, the procedure developed by Granger (1969) remains the most convenient and popular statistical test for causality and is therefore applied in this case.

The basic logic of the Granger Causality procedure is that current price levels predict future price levels. Researchers have therefore generally relied on the use of historical information for making forecasts about future outcomes, with the term, "granger-cause" being employed to link past and present events to future events. On the basis of the foregoing, model is formulated as follows: 


$$
\begin{gathered}
\mathbf{F G P}_{\mathbf{t}}=\sum_{i=\mathbf{1}}^{n} a i W S P t+\sum_{i=\mathbf{1}}^{n} b i F G P t-1+\mathbf{U}_{\mathbf{1}} \\
\mathbf{W S P}_{\mathbf{t}}=\sum_{i=\mathbf{1}}^{n} c i W S P t+\sum_{i=\mathbf{1}}^{n} d i F G P t+\mathbf{U}_{\mathbf{2}}
\end{gathered}
$$

Where:

$\mathrm{FGP}_{\mathrm{t}}$ represents the current farmgate or producer prices (time $t$ being the current period), and

$\mathrm{WSP}_{\mathrm{t}}$ represents the wholesale price in the current period (time $t$ ).

The postulation of the first equation is that the current farmgate price $\left(\mathrm{FGP}_{\mathrm{t}}\right)$ is influenced by the price that prevailed in the previous period, that is the $\left(\mathrm{FGP}_{\mathrm{t}-1}\right)$ as well as the past and current period wholesale prices $\left(\mathrm{WSP}_{\mathrm{t}}\right)$. The second equation makes similar assumptions in respect to the wholesale price $\left(\mathrm{WSP}_{t}\right)$ which is hypothesized to be determined by its historical levels as well as prices that prevailed further down the value chain. The error terms $\left(\mu_{1 \mathrm{t}}\right.$ and $\left.\mu_{2 \mathrm{t}}\right)$ are assumed to be uncorrelated.

Within this framework, four causality relationships are encountered and appropriate tests are available to isolate them as follows:

1) Undirectional causality which assumes that causality moves from $\mathrm{WSP}_{\mathrm{t}}$ to $\mathrm{FGP}_{\mathrm{t}}$ under the further assumption that the estimated coefficients on the past period $\mathrm{WSP}_{\mathrm{t}}$ in equation $(1)$ are statistically different from zero $\left(\sum \mathrm{a} \neq 0\right)$ while the estimated coefficients on the past period or lagged $\mathrm{FGP}_{\mathrm{t}}$ in equation (2) are statistically not different from zero $\left(\sum \mathrm{d}_{\mathrm{i}}=0\right)$. The implication is that reverse causation is possible in this case.

2) Unidirectional causality which assumes that movement is from $\mathrm{FGP}_{t}$ to $\mathrm{WSP}_{\mathrm{t}}$ is implied when estimated coefficient on past period farm gate price $\left(\mathrm{FGP}_{\mathrm{t}-1}\right)$ as presented in equation (2) is statistically different from zero $\left(\sum \mathrm{d}_{\mathrm{i}} \neq 0\right)$ while the estimated coefficient on the past period wholesale price $\left(\mathrm{WSP}_{\mathrm{t}-1}\right)$ in equation $(1)$ are jointly statistically not different from zero $\left(\sum \mathrm{a}_{\mathrm{i}}=0\right)$, suggesting that causation moves in only one direction.

3) Independence suggests a situation of neutrality because both sets of the lagged exogenous variable are apparently not statistically different from zero $\left(\sum \mathrm{a}_{\mathrm{i}}=0\right.$ and $\left.\sum \mathrm{d}_{\mathrm{i}}=0\right)$, such that no causal relationship exists between the variables.

4) Bilateral causality or feedback is the other extreme case when both sets of the lagged exogenous variables are statistically significantly different from zero in the two equations $\left(\sum \mathrm{a}_{\mathrm{i}} \neq 0\right.$ and $\left.\sum \mathrm{d}_{\mathrm{i}} \neq 0\right)$, suggesting that causality can move in either direction.

Once the direction of causality has been established, the next logical step in the analysis, following Guvheya et al. (1998), is to test the hypothesis of asymmetric price transmission. What is sought in this case is to what extent price increases and decreases at the point determined above are transmitted symmetrically to the next level. When a market shows signs of asymmetric price transmission, there is some suggestion that that market is not in perfect competition since free and unfettered flow of information among participants is a condition for efficient signaling function of prices. According to Tomek and Robinson (1990), asymmetric or sticky price behavior suggests imperfectly competitive markets and is indicative of imbalance in the distribution of information between market participants.

In order to perform the foregoing procedures, the following new variables were created.

$\mathrm{CWSP}_{\mathrm{t}}$ (change in wholesale price) $=\mathrm{WSP}_{-\mathrm{WSP}_{\mathrm{t}-1}}$

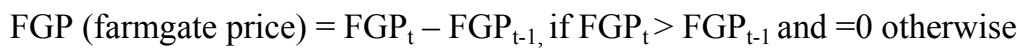

$\mathrm{FGD}$ (farmgate price decrease) $=\mathrm{FGP}_{\mathrm{t}}-\mathrm{FGP}_{\mathrm{t}-1, \text { if }} \mathrm{FGP}_{\mathrm{t}}<\mathrm{FGP}_{\mathrm{t}-1}$ and 0 otherwise

$\mathrm{CRP}=($ change in retail price $)=\mathrm{RP}_{\mathrm{t}}-\mathrm{RP}_{\mathrm{t}-1}$

Employing an approach now known as the "Houck procedure". Houck (1977) applied the technique of Rudolf (1971) to investigate the existence of asymmetric price transmission. Assuming that unidirectional causality is indicated and the path is from farmgate prices (FGP) to wholesale prices (WSP), what Houck hypothesizes is that unit increases in farmgate and producer prices will have different absolute effects on farm prices, respectively. For instance, while a unit increase in farm gate price would probably raise farm prices in absolute 
terms, a unit decrease in producer prices may not proportionately lead to a decrease in farm price even if some decrease occurs.

The Houck procedure simply fits an ordinary least squares (OLS) model in first differences along the lines of:

$$
\mathrm{CWSP}=\mathrm{a}_{0}+\mathrm{a}_{1} \mathrm{FGP}+\mathrm{a}_{2} \mathrm{FGPD}_{1}+\mu_{\mathrm{t}}
$$

Where:

$\mathrm{a}_{0}$ is the intercept term,

$a_{1}$ measures the strength of the contribution of farmgate prices to wholesale prices when farmgate prices are increasing,

$a_{2}$ measures the strength of the contribution of farmgate prices on wholesale prices when farmgate prices are decreasing, and

$\mu$ is the error term.

As Guvheya et al. (1998) observe, if the coefficient for a price increase is different from that of a price decrease $\left(a_{1} \neq a_{2}\right)$, non-reversibility or asymmetry occurs in CWSP. By convention, an F-test is used to test for the statistical differences between the two coefficients.

\section{Results and Discussion}

\subsection{Marketing Cost and Margin}

Marketing margin of wood charcoal is defined as the difference between the farmgate price of a kilogram of wood charcoal and the retail price. The wholesalers' and retailers' marketing margin were expressed as percentages of the retail price. On the other hand, the producer's share of the retail price is the retail price less the value of the (wholesale and retail) marketing margin.

The result of the analysis shows that the wholesale marketing margin was $22.3 \%$, while that of the retailers marketing margin was $21.29 \%$. The producer's share of the consumer's spending was $56.41 \%$. This implies that for every 1 spent by a consumer on $1 \mathrm{Kg}$ of wood charcoal, about 56kobo goes to the producers, while about 44kobo goes to cover the middlemen's marketing costs (1USD = about 150 Nigerian naira).

From the result, the sum of marketing margin for the middlemen $(43.59 \%)$ was lower than the producer's share (56.41\%). Enete (2003) reported marketing margin of 50\% for fresh cassava root in Nigeria. Goossens (1996) observed that margins can be as high as $45 \%$ for cassava products in Democratic Republic of Congo (DRC). Ebe (2007) observed a marketing margin of $46 \%$ for fuelwood in Enugu state Nigeria. The marketing margin of $44 \%$ as reported in this study could be considered high. Riley (1972) had reported that, for the most part, a retail margin of less than $10 \%$ of the consumer price seems normative for efficient markets in developing countries for non-perishable goods like charcoal. However, higher marketing margins often occur and reflect poor socio-economic environment of the actors, including other technical and institutional constraints (Goossens, 1996; Enete, 2003).

\subsection{Organisation}

Organization here implies the channel of marketing operations, as well as existence of charcoal association. Marketing channel is the chain that links producers and consumers of wood charcoal (Achumba \& Osuagwu, 1994).

From the analysis of our data, wood charcoal market flows through four (4) major marketing channels represented diagrammatically in Figure 1: 


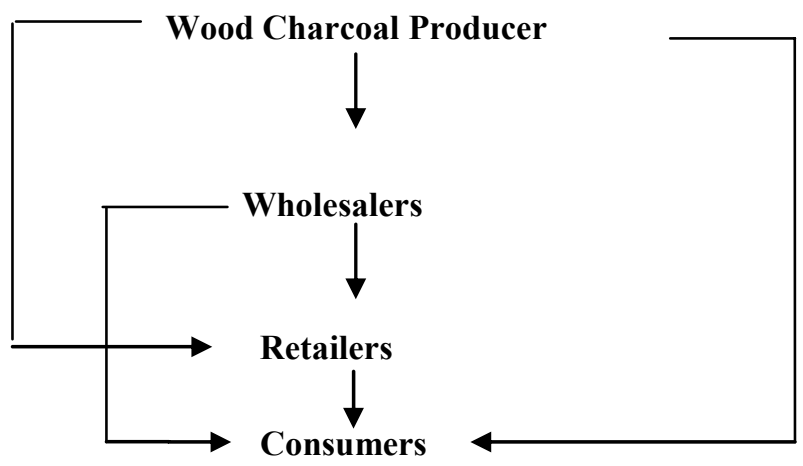

Figure 1. Marketing channel of charcoal in the study area

Figure 1 shows that the intermediaries operating between the wood charcoal producer level and the consumer level are mostly of two categories, namely wholesaler and retailer. Ebe (2007) also reported two intermediaries categories between the supplier and consumer of fuelwood in Enugu State, Nigeria. Enete (2003) observed three intermediaries and consumer of fuelwood of processed cassava products in Africa. The wholesale dealers buy from producers and sell to the retailers. The retailer in turn sells to the consumer in small quantities. However, some small scale retail shops in Umuahia town (Uzuakoli Road, Bende Road, etc.) and Aba town (New market, Ariaria International market, etc.) buy directly from producers. Also, some consumers like hotels buy directly from the producers or the wholesalers. Field data collected also show that there was absence of wood charcoal association or union.

\subsection{Structure of Wood Charcoal Market}

The structure of the wood charcoal market was analyzed. The importance of market structure for pricing and competition has been emphasized in the literature (for instance, Sayaka, 2006; Ugwumba, Okoh, \& Uzuegbunam, 2011; Obaji, 2011; among others). How the different levels of action in the chain are related with one another is crucial both for the ease with which consumers can access the commodity and the size of the earnings that suppliers/producers realize for their efforts. Since poverty reduction is one key goal of the involvement in production and marketing of wood charcoal, it is important to analyze the market sufficiently to understand the nature competition and the extent of market concentration. Among the various approaches for measuring the degree of competition and market concentration, the Gini Coefficients for wood charcoal were calculated for the producers, wholesalers and retailers in different markets. The results are presented in Table 1.

Table 1. Gini coefficient by level of marketing agents

\begin{tabular}{lllll}
\hline Marketing Agent & Gini & STD & Minimum & Maximum \\
\hline Producer & 0.356517 & 0.027073 & 0.301881 & 0.411154 \\
Wholesaler & 0.244510 & 0.025296 & 0.193496 & 0.295525 \\
Retailer & 0.347858 & 0.33705 & 0.279887 & 0.415830 \\
\hline
\end{tabular}

Source: Computed using E-views from the field data.

Table 1 shows that the Gini coefficient varied across different levels of the marketing chain for wood charcoal. As the results show, for wood charcoal producers, the Gini coefficient was 0.36 or $36 \%$. This result is close enough to equality at that level among the market participants, that is the producers. The indication is therefore that market concentration is low at the producer level of the wood charcoal value chain, suggesting that no single producer controlled a large enough volume to be considered dominant. Statistics generated by the United Nations Development Programme, (UNDP) suggests that Gini coefficient in the range of 0.5 and 0.7 imply greater inequality within the market, such that there are some substantially influential entities as well as those that command visibly insignificant volumes and therefore least influential (UNDP, 1992). This therefore suggests that most producers were not able to control large shares of wood charcoal supply in the study area implying that none could influence supplies by increasing or decreasing the quantity she/he produces. Each 
producer's output was an insignificant part of volume of trade in the market such that it could not affect the market price.

Table 1 also shows that the concentration of sales volume among wholesalers was low at an average of 0.24 or $24 \%$, with a range of 0.19 and 0.30 . Again, this result implies that none of the wholesalers controlled a significant proportion of the wood charcoal market to exert undue influence in the market. Similarly, the concentration of the retailers was low at an average of 0.35 with a range of 0.28 to 0.42 , meaning that retailers were relatively atomistic, each buying and reselling small quantities as shown in Table 1 with a similar trend i.e none of the retailers controlled the market.

Overall, the structure of the wood charcoal market indicated that there were many small scale dealers such that none could control the market. This type of market structure is competitive, because the individual agents have little or no influence on the market price. Nweke et al. (2002), Enete (2003), and Haggblade (2012), have made similar observations with cassava in Nigeria and several countries in sub-Saharan Africa where the commodity is traded within a perfectly competitive market structure featuring large number of suppliers and buyers of a homogenous product. Akinpelu and Adenegan (2011) and Ugwumba, Okoh and Uzuegbunam (2011) have also conducted price-concentration studies for the sweet potato and live-catfish markets in Anambra and Abia States of Nigeria, respectively. Hayami, Kikuchi, and Marciano (1999) also made similar observations with rice in the Philippines. With respect to the homogeneity of wood charcoal in the study area, $100 \%$ of the producers, wholesalers and retailers claimed the product could not easily be distinguished from the others. This is hardly surprising in view of the nature of the product which is derived from the combustion of fuel wood that results in a product that has unique appearance and texture regardless of where it is made and by whom. So, the same degree of product homogeneity that characterizes basic agricultural products is observed in this case.

\subsection{Price Causality Test}

Price Causality Tests were conducted to investigate the questions of price causality between producers and wholesalers and between wholesalers and retailers. The pairwise Granger Causality results are presented in Table 2.

Table 2. Pairwise granger causality results

\begin{tabular}{lccl}
\hline Null Hypothesis & Obs & F-Statistics & Probability \\
\hline 1. Producer-Wholesaler & & & \\
$\quad$ WSP does not granger cause FGP & 1302 & 2.64683 & 0.10400 \\
$\quad$ FGP does not granger cause WSP & 1302 & 11.6037 & 0.00068 \\
2. Wholesaler-Retail & & & \\
RP does not granger cause WSP & 1355 & 10.6606 & 0.00112 \\
WSP does not granger cause RP & 1355 & 15.5293 & 0.000085
\end{tabular}

Source: Computed using E-views Field DataNote: FGP = farmgate price; WSP = wholesale price; RP = retail price.

\subsubsection{Producer - Wholesale Level Price Causality}

Results of Granger causality test conducted on prices obtained for the exchange between producer and wholesale levels of the chain indicate an inter-relationship between their present and past values. The F-statistic probabilities indicate that using a decision rule of $\alpha=0.05$, the second hypothesis that says that FGP does not granger cause WSP is rejected while the first hypothesis is accepted. In order words, FGP causes WSP but not the reverse. This suggests that changes in producer price drive changes in wholesale price and hence, prices are determined at the producer's level. This result is surprising because there is a general belief that middlemen exploit producers of agricultural products and consumers through monopoly pricing and usury (Hayami et al., 1999), such that prices are determined at the middlemen level. However, research by Enete (2003) on the role of middlemen in smallholder cassava marketing suggests that cassava farmers, on average, handle higher volumes of marketed cassava products than middlemen and hence, had greater power of dictating the direction of the market. Hayami et al. (1999) also reported a highly competitive rice market in the Philippines where countless number of middlemen compete, leaving little room for monopoly/monopsony exercises. 


\subsubsection{Wholesaler - Retail Level Price Causality}

Results of Granger causality tests on prices prevailing between wholesale and retail levels indicate even a stronger interrelationship between their present and past values. Using the same decision rule of $\alpha=0.05$, we reject both hypotheses (WSP does not granger cause RP, and RP does not granger cause WSP) and conclude with $95 \%$ confidence that there is a feedback or bilateral causality relationship existing between the wholesale and retail price.

Importantly, we conclude that there was a unidirectional flow from the FGP to WSP, while there was a bilateral flow between WSP and RP.

\subsection{Asymmetry in Price Transmission}

Having established that wood charcoal price is determined at the producer's end of the marketing chain, asymmetry in price transmission from producer to wholesaler was tested by means of the Houck Procedure. The results of the test are presented in Table 3.

Table 3. Application of the houck procedure in producer - wholesale price transmission

\begin{tabular}{|c|c|c|c|c|c|}
\hline Variables & & Coefficient & S.E. & T-statistic & Probability \\
\hline Constant & -7.7449 & 15.3148 & -0.51 & 0.616 & \\
\hline FGPI $_{t}$ & & 0.8365 & 0.1345 & 6.11 & 0.0000 \\
\hline $\mathrm{FGPD}_{\mathrm{t}}$ & & -0.7030 & 0.1324 & -5.31 & 0.00 \\
\hline
\end{tabular}

R Squared $=0.7166 ;$ Adj R Squared $=0.7025$; Probability (F-statistics) 0.000 .

Source: Computed using E-Views from Field Data.

Testing for price transmission asymmetry entails an assessment of the degree of equality in the coefficients of farm gate prices at the two points, increasing (FGPI) and decreasing (FGPD).

Asymmetry in price transmission occurs when the coefficient for price increase is statistically different from the coefficient for price decrease. At 40 degrees of freedom (43-3), the calculated F-value (100.960) exceeded the critical F-value (50.58) at 5\% level of significance. Hence, the null hypothesis of equality of the coefficients $\mathrm{a}_{1}$ and $\mathrm{a}_{2}$ is rejected while the alternate of statistical difference between increasing producer price and decreasing producer price is accepted with $95 \%$ confidence. Price transmission from producer to wholesale level is therefore asymmetric.

According to the regression result, $84 \%$ of a $\$ 1$ increase at producer price level is immediately transmitted to the wholesale level, whereas $70 \%$ of a 1 price decrease at producer level would immediately be transmitted to the wholesale level. The implication of this is that producers transmit price increase faster to the wholesalers than price decreases. As concluded by Guvheya et al. (1998) in respect of the horticultural market in Zimbabwe, wholesalers transmit price increases faster to the producers than price decreases.

\section{Conclusion}

Wood charcoal marketing margins were generally high, apparently due to poor socio-economic environment of the actors. The margins were however, on the average, lower than the producers share of the consumer spending. The result also suggests a competitive market structure for wood charcoal in the study area. Prices were determined at the production level of the chain, but producers were asymmetric in their price transmissions to the wholesale level. These observations suggest that policy intervention in the form of improving the socio-economic environment under which marketing agents operate and facilitation of market information flow could improve wood charcoal marketing in the study area.

\section{References}

Achumba, I. C., \& Osuagwu, L. (1994). Marketing fundamentals and practice, Al-Marks Educational Research Inc., Enugu.

Agbugba, I. K. (2008). Economic analysis of wood charcoal marketing in Abia state, Nigeria. M.Sc thesis, Department of Agricultural Economics, UNN.

Akinpelu, A. O., \& Adenegan, K. O. (2011), Performance of Sweetpotato Marketing System in Umuahia Market, Abia State, Nigeria. Continental Journal of Agricultural Economics, 5(1), 7-13. 
Ardayfio-Schandorf, E. (1998). The woodfuel/Energy Crisis in sub-Saharan Africa. Retrieved from http://www.unu.edu/unupress/unpbooks/80918e/80918EOU.htm

CIFOR. (2005). Contributing to African development through forests. Centre for International Forestry Research. Retrieved from http://www.cifor.cgiar.org/publications/pdf-files/brochures/BCIFOR050.pdf

Cognitive Enhancement Research Institute. (2013). Retrieved 23 January, 2013, from www.ipcc.ch/pdf/technical-papers/climatechange-water-en.pdf

Ebe, F. E. (2007). Economic study of fuelwood marketing and consumption in Enugu state Nigeria. PH.D thesis, UNN.

Enete, A. A. (1999). The performance of plantain marketing in south-east Nigeria. A Seminar Paper, Department of Agricultural and Environment Economics. K. Leuven, Belgium.

Enete, A. A., \& Agbugba, I. K. (2008). Analysis of charcoal marketing in Abia state of Nigeria. Proceedings of the $22^{\text {nd }}$ Annual National Conference of the farm Management Association of Nigeria (pp. 338-346).

Enete, A. A. (2003). Resource use, marketing and diversification decision in cassava producing households of sub Saharan Africa. PH.D thesis, KU Leuven

FAO. (1981). The woodfuel situation in developing countries. Food and gricultural organization, Rome, Italy.

FAO. (1983). "Simple Technologies for Charcoal Making", FAO Forestry Paper 41, Rome, Food and Agriculture Organization of the United Nations.

Garland, S. (2005). Diversity, globalization and the ways of nature. Retrieved from http://www.idrc.calen/en-64509-201-1-DO-Topic.html-67K

Goossens. (1996). Cassava production and marketing in Zaire. Leuven University press, Leuven, Belgium.

Guvheya, G., Mabaya, E., \& Christy, R. D. (1998). Horticultural marketing in Zimbabwe: Margins, price transmission and spatial market integration. Paper presented at the 57th European Association of Agricultural Economists Seminar. Wageningen, The Netherlands, 23-26 September, 1998.

Haggblade, S. (2012), Cassava Commercialization in Southeastern Africa. Journal of Agribusiness in Developing and Emerging Economies, 2(1). http://dx.doi.org/10.1108/20440831211219219

Hayami, Y., Kikuchi, M., \& Marciano, E. B. (1999). Middlemen and peasants in rice marketing in the Philippines. Agricultural Economics, 20, 79-93. http://dx.doi.org/10.1016/S0169-5150(98)00082-6

Houck, J. P. (1977). An approach to specifying and estimating non-reversible functions. American Journal of Agricultural Economics, 59, 570-572. http://dx.doi.org/10.2307/1239663

Ministry of Lands, Survey and Urban Planning. (2010). Political Map of Abia State, MOLSUP, Umuahia, Abia state.

Morgan, W. B., \& Moss, W. (1981). Fuelwood and rural energy production and supply in the humid tropics, United Nations University, Tokyo and Tycolly International, Dublin.

National Population Commission. (2006). Population Figures, NPC, Umuahia, Abia state.

Nweke, F. I., Spencer, D. S. C., \& Lynam, J. K. (2002). The Cassava Transformation: Africa's Best Kept Secret. East Lansing: Michigan State University Press.

Obaji, R. N. (2011). The Effects of Channels of Distribution on Nigerian Product Sales. International Business \& Economics Research Journal, 10(2), 85-92.

Ogunkunle, A. I. J., \& Oladele, F. A. (2004). Ethnobotanical study study of woodfuel and timber wood consumption and replenishment in Ogbomosho, Oyo state, Nigeria. Environmental Monitoring and Assessment, 91(1-3), 223-236. http://dx.doi.org/10.1023/B:EMAS.0000009238.10891.c0

Riley, H. (1972). Improving internal marketing systems as part of national development systems, Occasional Paper no 3. East Lansing: Michigan State University, Latin American Studies Center.

Sayaka, B. (2006). Market Structure of the Corn Seed Industry in East Java. Jurnal Agro Ekonomi, 24(2), 133-156.

Taylor, C. J. (1963). Tropical forestry with particular reference to West Africa. London: Oxford University Press. 
Tomek, W. G., \& Robinson, K. L. (1990). Agricultural product prices. Ithaca, New York, USA: Cornell University press.

Ugwumba, C. O. A., Okoh, R., \& Uzuegbunam, N. (2011). Market Structure of Live-Catfish in Anambra State, Nigeria. Journal of Agriculture \& Social Sciences, 7(1), 25-29.

UNDP. (1992). The importance of forestry statistics. United Nations Development Programme. Retrieved from http://www.atyponlin.com/CFA/doi /abs/-10.1505/ifor.8.1.4

United States Department of Agriculture (USDA). (1961). Charcoal Production, Marketing, and Use. Report No. 2213, Forest Products Laboratory, Madison Wisconsin, and United States Department of Agriculture Forest Service (In cooperation with the University of Wisconsin).

Woodhead, L. (2005). Forestry and timber: wood for energy. Forestry show at Exeter Recourse on Friday 16th September, 2012.

World Resources Institute. (2005). Environmental income by ecosystem. Retrieved from http://www.multimedia.wri.org.wr2005/index.html-14k

\section{Copyrights}

Copyright for this article is retained by the author(s), with first publication rights granted to the journal.

This is an open-access article distributed under the terms and conditions of the Creative Commons Attribution license (http://creativecommons.org/licenses/by/3.0/). 